\title{
Characterization and Antibacterial Activity Test of Hand Sanitizer Gel Ethanol Extract Ficus lyrata Warb Against Escherichia coli Bacteria
}

\author{
Dwi Wahyudha Wira \\ Study Programme of Veterinary \\ Medicine \\ Faculty of Medicine, Universitas \\ Padjadjaran \\ Bandung, Indonesia \\ dwi.wahyudha@unpad.ac.id
}

\author{
Efri Mardawati \\ Departement Agroindustrial \\ Technology \\ Faculty of Agroindustrial Technology, \\ Universitas Padjadjaran \\ Bandung, Indonesia \\ efri.mardawati@unpad.ac.id
}

\author{
Hilma Erma Kamila \\ Departement Agroindustrial \\ Technology \\ Faculty of Agroindustrial Technology, \\ Universitas Padjadjaran \\ Bandung, Indonesia \\ krisbian.hilma@unpad.ac.id
}

\author{
Selly Harnesa Putri \\ Departement Agroindustrial \\ Technology \\ Faculty of Agroindustrial Technology, \\ Universitas Padjadjaran \\ Bandung, Indonesia
}

\author{
Roostita L. Balia \\ Study Programme of Veterinary \\ Medicine \\ Faculty of Medicine, Universitas \\ Padjadjaran \\ Bandung, Indonesia \\ roostita@gmail.com
}

\begin{abstract}
Diarrhea is a disease caused by the lack of maintenance of hand hygiene. One of the pathogenic bacteria that causes diarrheal disease is Escherichia coli. The way to maintain the hygiene of the hands of pathogenic bacterial attacks is to use antiseptic. The type of antiseptic that can be applied is Hand sanitizer. Ficus lyrata Warb is an annual plant known as the shade and protective plant. Ficus lyrata fruit has the content of phenolic compounds, flavonoids and tannins, which have the potential to be an anti-bacterial. The purpose of this research is to find out the antibacterial activity of Ficus lyrata fruit extract in hand sanitizer to reduce the number of bacteria on the hands. This type of research is experimental laboratories. Ficus lyrata Warb Fruit Extraction uses a maceration method with $70 \%$ ethanol solvent. The Ficus lyrata Warb fruit extract is made from a variety of concentrations of $100 \%, 75 \%, 50 \%$ and $25 \%$ tested antibacterial activity against Escherichia coli bacteria using the disk diffusion method with Amoxicillin as positive control and DMSO $50 \%$ as negative control. Effectiveness of the hand sanitizer with Ficus lyrata fruit extract in the hand, is tested using the Total Plate Count (TPC) method. Research Data is analyzed descriptively. The test results of antibacterial activity at a concentration of $75 \%$ resulted in the average diameter of the largest barrier of 1.75 mm but not greater than the positive control of $26,25 \mathrm{~mm}$. The result of TPC test, Hand sanitizer Ficus lyrata Warb fruit extract is able to reduce the number of bacteria on the hands from $0.90 \times 102 \mathrm{Cfu}$ 's $/ \mathrm{mL}$ to $0.30 \times 101 \mathrm{Cfu}$ 's $/ \mathrm{mL}$
\end{abstract}

Keywords-Antibacterial, Escherichia coli, Ficus lyrata Warb, Hand sanitizer, Total Plate Count (TPC)

\section{INTRODUCTION}

The hand is a member of the human body that can cause disease. The disease suffered by many people of all ages until now is diarrhea. One cause of this disease is a bacterial infection. Bacteria that are dangerous and can cause infections are pathogenic bacteria. These bacteria include Escherichia coli, Stapylacoccus sp, and Psedeumonas aeruginosa bacteria [1]

Efforts to prevent people from all kinds of bacterial infections is to use antiseptics that can be produced from natural materials, with this can utilize the available natural wealth. The use of antiseptics on hands has been used since the early 19 th. Its practical and more efficient use than washing hands with water alone has begun to spread in the community. An alternative antiseptic that can be used is the hand sanitizer. One of the plants that has potential as a natural antibacterial is the fruit Ficus lyrata Warb. An alternative antiseptic that can be used is the hand sanitizer. This is proven by the ability of the hand sanitizer to reduce the number of bacterial colonies on the hands.

The Ficus lyrata Warb is a family of Moraceae which is an annual plant that functions as a shade and protector Compounds contained in the Ficus lyrata Warb plants include flavonoids, alkaloids, saponins, coumarin, tannins, phenolic compounds, and terpene compounds that can function as antioxidants, anticancer, anti-inflammatory, antimicrobial, and can inhibit the growth of pathogenic bacteria [2].That Ficus lyrata Warb fruit extract has bioactive compounds such as phenol compounds, flavonoids, and tannins which have natural antimicrobial activities that have been tested on chicken carcasses and pathogenic bacteria.

Through this research, the antibacterial activity test and the number of hand sanitizer colonies from fruit extract have been tested. The extract was obtained by maceration method using ethanol solvent then evaporated to produce a thick extract, then the thick extract will be tested for antibacterial activity against Escherichia coli bacteria with 
disk diffusion method and made hand sanitizer then tested using the Total Plate Count method.

The purpose of this study was to determine the effect of the concentration of ethanol extract of Ficus lyrata Warb fruit on the characterization of hand sanitizer in reducing the number of bacteria on the hands.

\section{MATERIALS AND METHODS}

\section{A. Raw Material}

The fruit of Ficus lyrata Warb , 70\% ethanol, distilled water, 50\% DMSO, Bacterial Broth (AB), Nutrient Broth (NB), test bacteria (Escherichia coli ATCC 11229), glycerin, carbopol 940, triethanolamine (TEA), methyl paraben, amoxicillin, PCA, bunsen, disc paper, filter paper, aluminum foil, plastic wrap, and milli $\mathrm{Q}$ water.

\section{B. Crude Extraction}

$300 \mathrm{~g}$ of dried powder was extracted in $2.4 \mathrm{~L}$ etanol 70 $\%$ for $48 \mathrm{~h}$. The sample is filtered to produce filtrate, the filtrate is put into a rotary evaporator at a pressure of 100 $\mathrm{rpm}$ at $45^{\circ} \mathrm{C}$ to produce a thick extract. The resulting thick extract was allowed to stand until the ethanol solvent evaporated, then dilution was done using 50\% DMSO with a concentration of $100 \%, 75 \%, 50 \%, 25 \%$.

\section{Hand Sanitizer Product}

Carbomer 940 was weighed as much as $0.5 \mathrm{~g}$ and put into a beaker glass containing $20 \mathrm{~mL}$ of distilled water that had been heated, stirred until fluffy, Added Tritanolamin (TEA) as much as 2 drops and stirred, Added methylparaben as much as $0.2 \mathrm{~g}$ and dissolved in alcohol as much as $5 \mathrm{~mL}$ of distilled water, then stirred, plus $25 \mathrm{~mL}$ of Ficus lyrata Warb fruit extract, Added glycerin, stirred, Added distilled water to a total volume of $100 \mathrm{ml}$.

\section{Analysis}

\section{Antibacterial activity}

Antibacterial testing was carried out using the disk diffusion method, where four different treatments were given, namely $100 \%, 75 \%, 50 \%, 25 \%$ concentrations, plus positive control and negative control with 2 repetitions. The disc paper was immersed in a petri dish containing a sample solution with each concentration of $1 \mu \mathrm{L}$ then the petri dish containing disc paper was put in an incubator for 24 hours and measured the inhibition zones formed using calipers.

\section{Total Plate Count Test}

The sample is swab from the hand using a sterile swab, then the sample is put into a tube containing $0.9 \% \mathrm{NaCl}$ by $9 \mathrm{ml}$, then $1 \mathrm{ml}$ of sample is suspended and diluted to the desired extent. $1 \mathrm{ml}$ suspension was inoculated into a petri dish and added $15 \mathrm{ml}$ to $20 \mathrm{ml}$ PCA. The samples were incubated and counted for bacterial colonies using a colony counter.

\section{Physical Test of Hand Sanitizer}

The physical test was carried out by observing the hand sanitizer sample for 2 weeks with the observed factors were color, odor and consistency, $\mathrm{pH}$ and homogeneity

\section{RESULTS}

\section{A. Antibacterial activity}

The result of Ficus lyrata Warb fruit extract, formed in various concentrations $25 \%, 50 \%, 75 \%$, and $100 \%$, was tested on Escherichia coli bacteria grown on Sodium Broth media and able to produce inhibition zone diameters in the growth of these bacteria could be seen in Table I.

TABLE I. ANTIBACTERIAL ACTIVITY OF FICUS LYRATA WARB FRUIT EXCTRACT

\begin{tabular}{|c|c|c|}
\hline Concentration & Inhibitor Zone (mm) & Inhibition Category \\
\hline $\mathbf{1 0 0 \%}$ & $1 \pm 0.71$ & Low \\
\hline $\mathbf{7 5 \%}$ & $1.75 \pm 1.06$ & Low \\
\hline $\mathbf{5 0 \%}$ & $1.58 \pm 0.60$ & Low \\
\hline $\mathbf{2 5 \%}$ & $1,15 \pm 0,50$ & Low \\
\hline Positive Control & $26.25 \pm 0.35$ & Strongest \\
\hline Negative control & $0 \pm 0$ & Zero \\
\hline
\end{tabular}

\section{B. Total Plate Count Test}

The extract used was the extract which had the greatest average inhibition at a concentration of $75 \%$ of $1.75 \mathrm{~mm}$. TPC testing was carried out on 2 treatments namely before application and after application of hand sanitizer. The result could be seen in Table II.

\begin{tabular}{|c|c|c|}
\multicolumn{1}{c}{ TABLE II. } & \multicolumn{2}{c|}{ TPC TEST RESULTS ON HAND SANITIZER } \\
\hline \multirow{2}{*}{ Sample } & Before application & After application \\
\cline { 2 - 3 } & $3.00 \times 10^{2}$ & 0.00 \\
\hline $\begin{array}{c}\text { Hand sanitizer } \\
\text { with alcohol 70\% }\end{array}$ & $0.90 \times 10^{2}$ & $0.30 \times 10^{1}$ \\
\hline $\begin{array}{c}\text { Hand sanitizer } \\
\text { with Ficus lyrata } \\
\text { Warb fruit } \\
\text { Exctrac 75\% }\end{array}$ & \\
\hline
\end{tabular}

\section{Physical Test of Hand Sanitizer}

The physical test were carried out by observing the hand sanitizer sample for 2 weeks with the observed factors were color, odor and consistency. At the observations of weeks 1 and 2 did not change. The hand sanitizer with extract has a thicker consistency compared to alcohol because the use of extract is still concentrated. The result could be seen in Table. III. 


\begin{tabular}{|c|c|c|c|c|c|c|}
\hline \multirow{2}{*}{$\begin{array}{l}\text { Storage } \\
\text { (Weeks) }\end{array}$} & \multicolumn{2}{|c|}{ Color } & \multicolumn{2}{|c|}{ Aroma } & \multicolumn{2}{|c|}{ Consistency } \\
\hline & $A$ & $\bar{B}$ & $\bar{A}$ & $B$ & $\bar{A}$ & $\bar{B}$ \\
\hline 1 & $\begin{array}{c}\text { Trans } \\
- \\
\text { parant }\end{array}$ & $\begin{array}{l}\text { Brown- } \\
\text { Yellowi } \\
\text { sh }\end{array}$ & $\begin{array}{c}\text { not } \\
\text { specif } \\
\text { ic }\end{array}$ & $\begin{array}{l}\text { spesif } \\
\text { ic }\end{array}$ & $\begin{array}{c}\text { viscosity } \\
(++)\end{array}$ & $\begin{array}{c}\text { viscosity } \\
(+++)\end{array}$ \\
\hline 2 & $\begin{array}{c}\text { Trans } \\
- \\
\text { parant }\end{array}$ & $\begin{array}{l}\text { Brown- } \\
\text { Yellowi } \\
\text { sh }\end{array}$ & $\begin{array}{c}\text { not } \\
\text { specif } \\
\text { ic }\end{array}$ & $\begin{array}{l}\text { spesif } \\
\text { ic }\end{array}$ & $\begin{array}{l}\text { viscosity } \\
(++)\end{array}$ & $\begin{array}{c}\text { Viscosity } \\
(+++)\end{array}$ \\
\hline
\end{tabular}

Homogeneity observation on $70 \%$ alcohol hand sanitizer samples produced homogeneous gel without lumps or fine grains, whereas on hand sanitizer samples with Ficus lyrata Warb fruit extract produced non-homogeneous gel because there were still lumps and fine grains. The result could be seen in Table. 4.

\begin{tabular}{|c|c|c|}
\hline \multicolumn{1}{|c|}{ TABLE IV. } & \multicolumn{2}{c|}{ Result } \\
\cline { 2 - 3 } & Homogeneity & pH \\
\hline $\begin{array}{c}\text { Hand sanitizer with } \\
\text { alcohol 70\% }\end{array}$ & Homogeneity & 4.17 \\
\hline $\begin{array}{c}\text { Hand sanitizer } \\
\text { with Ficus lyrata } \\
\begin{array}{c}\text { Warb Fruit } \\
\text { Exctrac 75\% }\end{array}\end{array}$ & no Homogeneity \\
\hline
\end{tabular}

\section{DISCUSSION}

\section{A. Antibacterial Activity}

Based on Table 1. and it could be seen that each concentration of Ficus lyrata Warb fruit can form inhibitory zones on the Sodium Broth medium that has been grown by Escherichia coli bacteria. The average inhibition zones produced by Ficus lyrata Warb fruit extract respectively at a concentration of $25 \%, 50 \%, 75 \%$, and $100 \%$, namely 1.15 $\mathrm{mm} ; 1.58 \mathrm{~mm} ; 1.75 \mathrm{~mm}$; and $1 \mathrm{~mm}$. From these data, it could be seen that at a concentration of $75 \%$ the largest inhibitory zone was produced in Ficus lyrata Warb fruit extracts, with an average inhibition zone value of $1.75 \mathrm{~mm}$ each. While the smallest inhibitory zone extract was produced by fruit extract at a concentration of $100 \%$ with an average inhibition zone value of $1 \mathrm{~mm}$. This could be influenced by differences in viscosity in each extract.

Extracts with higher concentrations will have a higher viscosity as well, this can cause the extract to diffuse difficult to the media and affect the inhibition zone diameter results.The template is designed for, but not limited to, six authors. inhibition zone due to the influence of extracts on the growth of Escherichia coli bacteria. This happens because the Ficus lyrata Warb contains bioactive compounds, especially phenolic compounds, flavonoids, triterpenoids, and tannins [2]. These compounds were inhibiting the growth of pathogenic bacteria.

\section{B. Total Plate Count Test}

Based on the table above shows that the hand sanitizer without extract or using active ingredients alcohol successfully reduces the number of bacteria on the hands up to 0.00 . This is because the alcohol content used is $70 \%$ alcohol content which can inhibit bacteria, viruses, germs up to $90 \%$ because alcohol is very sensitive to protein deposition and enzyme performance. Whereas the hand sanitizer with active ingredients Ficus lyrata Warb fruit extract succeeded in reducing the number of bacteria on the hands up to $0.30 \times 101$. The decrease in the amount of bacteria on the hands caused by the presence of bioactive senayawa on Ficus lyrata Warb fruit which can inhibit bacterial growth. The most dominant active compounds was phenols and tannins. In phenols, the inhibitory mechanism is bound to proteins to form hydrogen bonds that inhibit protein synthesis and damage enzyme performance. Whereas in tannins is interfering with or attacking polypeptides (composed of several peptides) which are formed through DNA recapitulation so as to make the formation of bacterial cell walls become less perfect and cause bacterial cell lysis due to osmotic and physical pressure.

\section{Physical Test of Hand Sanitizer}

Base on Table 3. The physical test was carried out by observing the hand sanitizer sample for 2 weeks with the observed factors were color, odor and consistency. At the observations of weeks 1 and 2 did not change. The hand sanitizer with extracts has a thicker consistency compared to alcohol because the use of extracts is still dense. In addition, the thickness of the hand sanitizer is influenced by the composition of the carbopol percentage used, the greater the percentage of carbopol used, the thicker the gel produced on the hand. sanitizer [3]

Table 4. In observing the homogeneity of $70 \%$ alcohol hand sanitizer samples produced homogeneous gels without lumps or fine grains, while the hand sanitizer samples with rhino ketapang fruit extracts produced homogeneous gels because there were still lumps and fine grains. Homogeneity requirements are in the absence of coarse grains, the active ingredients used are evenly distributed and do not clot. [3] . Whereas based on the observation table above shows that both samples have a $\mathrm{pH}$ value below the skin $\mathrm{pH}$ standard which ranges from 4.5 to 6.5 . This is because every antiseptic that is in contact with the skin must have a $\mathrm{pH}$ that matches the ph of the skin, because if it is more acidic or more alkaline then it becomes more difficult to neutralize it. So that makes the skin becomes irritated, dry, cracked and easily infected. Harmonize the $\mathrm{pH}$ of the hand sanitizer is to add Triethanolamine (TEA) and glycerin. Because TEA functions as a gel stabilization, it has a $\mathrm{pH}$ of 10.5, is soluble in water, methanol, carbon tetrachloride and acetone [4]. 


\section{ACKNOWLEDGMENT}

Thank you to the Universitas Padjadjaran on behalf of the Universitas Padjadjaran Internal Grant through the Fundamental Research Scholarship program.

\section{REFERENCES}

[1] D. Katrin. "Test the Antibacterial Activity of the Extract Litsea graciae". Jkk. 4(1), 2015, pp. 7-12
[2] D.W. Wira. "Antimicrobial and Phytochemical Potential Study of Fruit Extract Ficus lyrata Warb as a Natural Preservative". Jurnal Teknotan. 2014, pp, 1-15

[3] Y.Wasiaturrahmah., R Jannah,.“ Formulation and Test of Physical Properties of Hand Sanitizer Gel from Leaf Extract Syzygium polyanthum. 2018, 2 (2), pp. 87-94.

[4] A. R. A. B. Asngad and N. Nopitasari. "Quality Handsanitizer Gel from Banana Stem Extract with Different Doses of Alcohol, Trichosan and Glycerin. Bioeksperimen: Jurnal Penelitian Biologi, 2018, 4(2), pp.61-70 